\title{
A Note on Punctuation and the Primitive
}

Once upon a time, an author could write a historical work confident that the object of knowledge that was the book's essential topic unfolded over time in a slow and orderly manner, and confident that "it" was the same thing, albeit changed with time, at the beginning and end of the story. That sort of conventional history produced titles like (I am making these up) "The Rise of the Family" or "Hysteria-from the Ancient Greeks to the Present Day." Their authors did not feel obliged to ask deeply, for instance, whether Greek "hysteria" shares anything whatsoever with present-day "hysteria" other than the Greek root of the English word, and therefore whether to write such a history makes any sense.

In years of late, Michel Foucault's work more than anyone else's destroyed the legitimacy of that mode of writing. The Foucaultfriendly premise on which this book is founded is that "primitive art" is not a timeless category existing in the abstract world of ideas and essences but a constructed category that appeared at a certain moment. Nor did the category remain stable once it was invented: both the semantic field in which the term exists and the objects gathered under its rubric changed over time and varied across contextsthose contexts being (for my purposes) institutional displays, markets, and collections.

To take that stance, however, forces the author of a history-even a loosely historical account like this book-to confront the issue of how to name something that is not the same thing in the story's beginning and end. One alternative to conventional history prompted by this dilemma and adopted by some historians is to make the methodology fully as important, sometimes more so, than the subject matter of their books, in order to emphasize and explicate the dilemma itself. In this book I have tried to take a more moderate course than either extreme (the two extremes being conventional history, which imagines the categories as transparent and constant, and 
a self-questioning history, heavy on abstract language and focused on method). But an author's moderation requires a tolerant reader. I know this because I have dealt with copy editors.

The necessity of writing an apologia pro verbis meis first occurred to me when a copy editor suggested changing my sentence that began "Freud's construction of the primitive ... " to "Freud's construction of indigenous people. ..." I have it on good authority that Freud wrote nothing whatsoever about "indigenous people," and although, like the copy editor, I do not want to offend, I also do not want to be anachronistic. The book is premised on the fact that the object of knowledge changes in different contexts and is constituted partly by the way it is named, the unmarked use of which in my own account, in what is obviously a historical context of a word's use, is supposed to evoke in my readers an idea that is specific to that era or context. To try to find a neutral language that names a constant object is precisely not what I am trying to do.

The reason for finding a "neutral language," I am well aware, is not because copy editors want to promote anachronism but because they rightly strive to avoid language that is disrespectful; that is obviously my wish, as well-although in this regard I can do no better than quote the art historian Frances Connelly, who wrote, "The derogatory connotations of the term 'primitive' have provoked efforts to find less value-laden substitutes. The real need is not for neutralized substitutes but for recognition that the term does not describe a Yoruba figure or an Egyptian relief, but a set of ideas belonging to Europeans." That said, it still remains true that the author of a work about the primitive and primitivism needs some devices to show ironic distance from terms that could be misinterpreted as being uttered in the author's own voice.

Occasionally I do want to show ironic distance from a term, in which case I sometimes capitalize the first letter of the word; for instance, in the introduction I make a point of capitalizing Reason, Objectivity, and some other terms. Several years ago, when one of this book's chapters was being published as an article, the copy editor changed my deliberately written Primitive Man (it may even have been a direct quote from a museum label) to primitive humans, in accordance with the journal's policy of not capitalizing ordinary words and eliminating sexist language. The new low-impact change (which fortunately was caught before cast in ink) did nothing to alert the 
reader that it was the museum's voice, not mine, that was speaking. I had written the words with initial caps to signal to the reader that the term is not my own and also to evoke recognition of a certain voice and mind-set that believes in the importance of its own pronouncements.

Other than the occasional initial capital, another punctuational tactic I use to show ironic distance is to put quotes around a term like "authentic primitive art" or "tourist art" the first time it is used or when I want to remind the reader that it names an ephemeral category or a changing one. The danger of not using the quotes at all is that a reader will not "hear" the premise of my argument (that authentic primitive art, or tourist art, or whatever, is a constructed category); yet if I always marked changeable categories with quotation marks, it would belabor what ought eventually to be obvious and would become irritating. Therefore, for the most part I have assumed that readers will understand the larger argument and will provide their own quotes around terms, tolerantly understanding that I am trying to spare them annoyance rather than that I am reifying a category.

When speaking in my own voice about actual people and their condition, I have used terms that are historically appropriate in the context of my text (such as "colonized people," or "people of Africa, Oceania, and the Americas," or "fourth-world people," or "people on the periphery of the global economic system") and sometimes specifically the ways that some groups currently are referring to themselves (Native Americans, Aboriginals of Australia, Canada's First People, the indigenes of Latin America-a translation of los indigenas rather than the now-derogatory indios), even though some of these names will persist only a few years, and there is debate among the communities themselves about appropriate terms (for instance, "American Indian" is favored over "Native American" by some). I trust that my readers, including those of the groups mentioned, will understand the short life of names and the changeability of what they denote. 
